\title{
The Militant Nun as Political Activist and Feminist in Martial Law Philippines
}

\author{
Mina Roces, University of New South Wales
}

The 1984 feature film Sister Stella L. had its main character Sister Stella say the activist slogan: 'Kung hindi tayo kikilos, sino pa, kung hindi ngayon, kailan pa! [If we do not act, who will, if not now, when else!] '(Reyes 1989) This slogan was one of the catchphrases of the activists of the 1970s. The fact that screenplay writer Jose Lacaba purposely gave these lines to the character who was a militant nun (not a priest or other activist) was testimony to the visibility of the militant nun as representative of opposition to the Marcos dictatorship. The plot of the movie involves a nun, Sister Stella Legaspi, who is initially politically indifferent, but who eventually becomes sensitised to the plight of the strikers during a labour dispute in a depressed area. Exposed to the miserable lives of the strikers, she joins them on the picket line, only to witness the military assault and murder of a labour leader. This experience strengthens her determination to fight against tyranny and oppression and she delivers that activist slogan at the climax of the film.

The fictionalised story of Sister Stella L. (played by film star Vilma Santos) depicted the militant nun's metamorphosis into political activist. Nuns were in fact interviewed and consulted by director Mike de Leon in the making of the film, thus presenting a relatively accurate image of the militant nun in the martial law years (1972-1986). ${ }^{1}$ It was the nun's exposure to the victims of martial law that inspired them to speak out for political detainees, support labour strikes, report on the abuses of the regime and later act as human barricades in the front lines that faced the military. But the nuns were not the only women political activists. There were many women who joined the Communist Party of the Philippines and their military arm the New People's Army (NPA). Women also filled the ranks of the Social Democrats, the terrorist group the April $6^{\text {th }}$ Liberation Movement, human rights reformist groups and the traditional political oppositionists,

\footnotetext{
${ }^{1}$ Interview with Sister Christine Tan, Leverisa, Malate, Metro-Manila, February 15, 1993.
} 
including those who were in exile abroad. But these women remained marginalised in those groups, were denied leadership positions and in most cases given administrative or caretaking responsibilities, which reinforced traditional gender roles of women as secretaries, writers, nurses, cooks and 'mothers' or child minders (Hilsdon 1995, p. 82). In contrast, the militant nuns, though still conforming to traditional gendered images of the woman as moral guardian, discovered that they had 'moral power'. In this sense, they became much more effective than the women in other radical organisations. Not seen as wanting official power, but revered as moral guardians, these militant nuns became a successful pressure group. First Lady Mrs Imelda Romualdez Marcos, for instance, invited Sister Christine Tan to Malacañang four times for 'discussions' (perhaps to win the nuns over), the invitation itself evidence of the potential clout of moral power. ${ }^{2}$ Sister Christine was later invited by no less than President Corazon Aquino to be a member of the Constitutional Convention of 1986. Nuns stood in front of military barricades to protect demonstrators from potential violence. In most cases, they did succeed in preventing military violence (as in the People Power revolution of 1986), although there were some nuns who suffered beatings and torture by the military.

This paper argues that it was the nuns' unique positioning as ambivalent women that gave them power and legitimacy as political activists. ${ }^{4}$ In contrast to other women in radical politics, these women succeeded in becoming visible leaders and symbols of political activism while acting as a pressure group vis-à-vis the dictatorship.

Traditionally, women are defined in terms of their kinship relations with men: as sisters, wives, mothers, daughters for example. Politics in the Philippines is not male-dominated but gendered: men exercised official power while women exercised unofficial power through their ties with male politicians - as wives, mothers, sisters, daughters and even mistresses of male politicians. Because Filipino concepts see power as held by the kinship group, women - though marginalised in official political positions - can exercise power as members of the kinship group. Women as the support system in kinship politics (the dominant dynamic in Philippine politics where political power is

\footnotetext{
${ }^{2}$ Interview with Sister Christine Tan, Leverisa, Malate, Metro-Manila, February 15, 1993.

${ }^{3}$ That is, their role as nuns unsettled traditional definitions of women by highlighting contradictory discourses about how women exercised power and the categories of traditional/modern woman.

${ }^{4}$ That is, their role as nuns unsettled traditional definitions of women by highlighting contradictory discourses about how women exercised power and the categories of traditional/modern woman.
} 
used to benefit the kinship group) are active political agents. Women as wives and kin of male politicians who exercise power through their male relatives are the political norm. Women radicals (apart from the nuns) shunned kinship politics, closing the door to power behind the scenes. Compelled to compete in a male dominated environment where male rules prevailed, these women radicals failed to claim leadership roles and were pushed aside as auxiliaries in the struggle for national liberation.

The militant nuns were theoretically unattached to men (though they still remained members of the kinship group, they lived in a world outside their families). And yet, by the end of the martial law period they had exercised power much like the traditional wives of politicians. Not claiming official power (or even desiring it), they were different from the other women in radical politics whose aim was to gain political power in the end. The nuns were much more similar to the traditional women, who as wives or kin of politicians acted as a pressure group behind the scenes. In fact, like these wives of politicians, they metamorphosed into 'politicians' themselves after exercising power behind the scenes first. Just as Mrs Marcos became Governor of Metro-Manila, Minister of Human Settlements and later Congresswoman after she exercised an enormous amount of power as First Lady, nuns like Sister Christine Tan (who became a Constitutional Convention delegate) and Sister Mary John Mananzan (who became chair of the Citizen's Alliance for Consumer Protection and president of GABRIELA, the umbrella group representing a myriad of women's organisations), claimed important political positions after they had exercised power behind the scenes during the martial law period.

Nuns were also ambivalent in the sphere of political power: they had 'moral power', but not political office. Their source of moral power was the Catholic Church and traditional definitions of the feminine, which conflated 'woman' with 'moral guardian'. In the provinces in particular, Assumption nuns traced their 'moral power' to the respect they earned from the community through their activities such as providing education for the poor, negotiating with sugar planters for better conditions for sacadas (migratory seasonal workers who are employed to harvest sugar cane), and generally supporting the 
campaigns of the oppressed (such as tribal women in Baguio, the highlands). ${ }^{5}$

Assumption nuns realised immediately that the Catholic Church in the Philippines was 'political' and that their 'moral power' was thus inevitably political. ${ }^{6}$ This moral-cumpolitical power was acknowledged not just by the authoritarian rulers, but also by the other opposition groups, such as the NPA (the New People's Army, the military arm of the Communist Party of the Philippines). Particularly in the provinces where the NPA had a strong influence, it realised that nuns could be political rivals or allies.

Assumption nuns, for instance, noticed that the NPA solicited their help. Conversely, at least one Assumption nun received death threats from the NPA. ${ }^{7}$

By the close of martial law, the nuns invoked this moral power in critical situations. This newly found power then stood in stark contrast to their marginalisation within the male dominated church hierarchy. I argue that the experience of martial law when they discovered moral power also transformed them into feminists. They became the first women to challenge cultural constructions of the feminine. ${ }^{8}$ Why? I suggest two possible explanations here. First of all, their ambivalent position as women unattached to men prevented them from practising kinship politics - in fact they represent the very antithesis of kinship politics (much more than the women in radical politics, who despite being theoretically opposed to kinship politics, discover that in practice this kind of politics is still alive and kicking within their organisations). Secondly, the nuns were confronted with the contradiction between their politically effective 'moral' power and their marginalisation within the male dominated church hierarchy. The realisation of this contrast between their political voice in a dictatorship and their ineffective voice within the church hierarchy may have triggered the first feminist consciousness. Martial

\footnotetext{
${ }^{5}$ Interview with Sister Gertrude Borres, Religious of the Assumption, Dean Assumption College, San Lorenzo Makati Metro-Manila, January 21, 2002, and interview with Sister Josefina Magat, Religious of the Assumption, President of the Assumption Convent, Assumption Convent, San Lorenzo Makati, Metro-Manila, February 1, 2002.

${ }^{6}$ Interview with Sister Gertrude Borres; interview with Sister Josefina Magat.

${ }^{7}$ Interview with Sister Gertrude Borres.

${ }^{8}$ In the late 1960s and 1970s, the first feminist organisation MAKIBAKA was formed, but when martial law was declared, it was forced to go underground and it later faded away. The women here were only beginning to challenge the cultural construction of the feminine, particularly the image of Maria Clara (submissive, vapid, demure, timid woman made 'ideal' through the character of Jose Rizal's novel). The suffragists of the 1920s entered the new public spaces opened to them for the first time (went to university, founded women's universities, joined the professions), but they did not confront definitions of the feminine; instead, they merely extended it to include other things. Hence the suffragists were also beauty queens (Carnival Queens), heads of civic organisations as well as founders of universities.
} 
law became the catalyst that transformed nuns into radicals and feminists. By the later years of martial law, their anti-dictatorship stance was expanded to include specific women's issues.

The nuns became the first women's group to challenge traditional cultural constructions of the feminine, form feminist organisations and then focus on trying to alter these traditional definitions of the feminine by teaching women's studies courses and supporting research on women's issues. A nun, Sister Mary John Mananzan, became the head of GABRIELA (General Assembly Binding Women for Reforms, Integrity, Equality, Leadership and Action), an umbrella organisation for around 200 women's groups in the early 1980 s.

The scholarly literature on women's organisations in the Philippines concentrates on the tension between feminism and nationalism, the discourse on the woman question, political activism, feminist perspectives, and descriptive accounts of the various women's groups. ${ }^{9}$ The consensus among these scholars is that, in the tension between feminism and nationalism, the priority of national liberation downplayed women's issues and prioritised other issues of social injustice, dictatorship, class struggle, democracy, violence and revolution. Primarily interested in women's activism in groups, scholars have chosen to focus only on groups that at one point or another may have grappled with the woman question (Claussen 1998). Hence, apart from women in the Communist Party of the Philippines (CPP), other women radicals who were members of radical groups composed of both sexes have not been examined from a gendered perspective. Exclusively women's organisations were the ones prioritised in the scholarly research, regardless of whether these groups utilised feminist perspectives or not; what mattered was that they had been associated with political opposition or with radical politics.

\footnotetext{
${ }^{9}$ On feminism and nationalism, see Angeles (1989) and Hilsdon (1995); on the feminist perspectives and/or feminist scholars see Hyndman (1992); for accounts of women's groups, see Santos-Maranan (1984); De Dios (1996); Gomez (1991); Ronquillo (1984); Tangcangco (1992); and for the feminist scholars' perspective, see Aguilar (1988 and 1994-1995).
} 
Thus the militant nuns, because they were not officially organised, were not given the prominence they deserved in the scholarly literature on women's organisations or activist women. This could be explained partly by the fact that they do not have a unified organisation with a name, and partly because the common perception was that they were dismissed as mga madre lamang, just nuns. A recent $\mathrm{PhD}$ dissertation, however, focused on the Benedictine nuns and their evolution into feminist nuns, but the analysis was located in the context of a nun's vocation. In 'Un(convent)ional Sisterhood: Feminist Catholic Nuns in the Philippines', Heather Lynn Claussen argued that the nun's feminism challenges the perspective that Philippine feminism evolves out of nationalist/communist mass movements, coming instead from nun's spirituality and being influenced by indigenous Philippine priestesshood and international sources (Claussen 1998: 201). Using the case study of the Benedictine nuns of St Scholastica's and relying quite heavily on the autobiography of one nun (who I suspect is Sister Mary John Mananzan, under the pseudonym Sister Justine), Claussen credits the nun's exposure to women's issues abroad, coupled with the observance of similar situations in the Philippine context, as the catalyst that inspires feminist consciousness. Furthermore, the very circumstances of nuns as unmarried (and thus celibate) women who as a sisterhood make decisions on their own, independently of men and outside the familial context, favourably position them as budding feminists (Claussen 1998, pp. 374-5). This view of the origins of the nuns' feminism is generally accurate and applies not only to the Benedictine nuns (Claussen's research) but also to other religious orders, such as the Religious of the Assumption. Many of the nuns were exposed to feminist ideas when they went overseas. But although their spirituality and their observance of women's oppression in the local context were cited as influential in their feminist awakening, the links with indigenous Philippine priestesshood were perhaps weaker in orders outside the Benedictines (Sister Mary John has written about the role of Filipino women in preHispanic times). While Claussen acknowledged that the Benedictine nuns were also affiliated with political and activist movements, including environmental activism, ${ }^{10}$ she did not single out political activism as an important step towards the evolution of the nuns' feminism (in fact she argued that feminism did not evolve out of nationalist/communist mass movements). Claussen argued that in the Benedictine order,

\footnotetext{
${ }^{10}$ Interestingly, the same story which Mary John revealed to me in an interview about her 'baptism of
} 
one nun could be singled out for building a group of feminist nuns in St Scholastica's. This nun, Sister Justine (perhaps Sister Mary John, who Claussen described as being somewhat of a 'legend' and a 'cultural heroine' was a 'key player in fanning the flames of Missionary Benedictine interest in, and commitment to a "feminism" fit for the Philippines' (Claussen 1998, pp. 374-5). This paper modifies Claussen's arguments by suggesting that it was the disparity between their moral power vis-à-vis a dictatorship and their lack of power in the Catholic Church, that triggered their feminist consciousness. Hence, political activism had some influence on the evolution of the nun's feminism. But certainly, exposure to feminism abroad was also critical to their conscientisation (to use the nun's term). On the whole, the militant nun-though acknowledged by everyone as the most visible symbol of martial law activism (epitomised by the film Sister Stella L.) — has been largely neglected by scholars of political activism and feminist scholars. This is regrettable, since the nuns (not the suffragists) were among the first to challenge traditional cultural constructions of the feminine in the Philippines. ${ }^{11}$

\section{Martial law and the birth of the militant nun}

The nuns were transformed into political activists almost immediately after martial law was declared in 1972. The plight of a vast number of political prisoners or detainees (many of whom were tortured and killed or salvaged) first attracted the attention of these women, who - because of their Christian vocation - staunchly believed in the causes of social justice. Eventually, the problems of labourers who participated in illegal strikes against low salaries and inappropriate working conditions, and the evictions of tribal groups from their lands compelled the progressive nuns to come out of their convents, braving arrest and military force. At first, it was the plight of the political prisoners that awakened issues of social justice and transformed the nuns into political radicals. Sister Mariani Dimaranan became the president of the Task Force Detainees or TFD, an organisation founded to document the predicament of political prisoners, to give them support, to lobby for their release, speaking out against their unjust

fire' appears in this account under the pseudonym Sister Justine.

${ }^{11}$ The Filipino suffragists were also beauty queens, civic workers and founders of women's universities. They did not challenge existing definitions of the feminine (especially as beauty queen) though they extended these definitions to include new roles in the new public spaces opened to women for the first time. See (Roces 2001). 
imprisonment and torture. Nuns were active from the very beginning of martial law, when most Filipinos, terrified of arrest, torture and death, kept quiet; when even the student radicals — so vehement in their demonstrations against President Marcos in the early 1970 s - either went underground or kept silent. The mob of angry student protesters who filled the streets in the late 1960s quickly vanished, but the militant nuns, with far less noise and more courage, consistently took to the streets to champion human rights. Sister Mariani's motivation for becoming a political activist was not the theology of liberation but the practices of the oppressive regime, which forced the religious women to confront the reason behind their decision to become nuns:

Ay no I think the theology of liberation contributed, but I think, humanly speaking, they were touched by the situation of oppression; for me that is it. Siempre, they saw the situation, they analyze also, and iyon nga, ang tanong mo sa sarili, bakit ako nagmadre? Hindi ba? Ano ang response ko sa situation na ganyan if I am a follower of Christ talaga? De siempre may vow ka ng poverty; ano ang gagawin ko? [I think the theology of liberation contributed, but I think, humanly speaking, they were touched by the situation of oppression; for me that is it. Of course, they saw the situation, they analyze also, and that's it. One asks oneself, why did I become a nun? Isn't it? What is my response to a situation like that if I am a true follower of Christ? Of course I have a vow of poverty, so what am I going to do? $]^{12}$

Due to her political involvement, Sister Mariani was arrested and detained in Camp Crame for fifteen days and Bicutan for thirty-two days. She was, however, not the only religious arrested in the simultaneous raids on convents, seminaries, Catholic schools, and dormitories. These religious premises were ransacked by the military in an official search for 'subversive materials': St Joseph's College (where Sister Mariani was college registrar), Our Lady of Angels Seminary, the Convent of the Oblate Sisters of Nôtre Dame, the Redemptorist monasteries in Davao and Tacloban, and the Good Shepherd Sisters in Matina, Davao, were also raided. On the orders of Defense Secretary Juan Ponce Enrile, St Joseph's College, too, was raided, because the military suspected it was a centre for the distribution of underground newspapers (Liberation 1973, pp. 1-2).

Witnessing the torture of political prisoners while she herself was under detention inspired Sister Mariani to join the Task Force Detainees and to take over the presidency in April 1975. Prior to that, an American Franciscan priest had been president for a few months, but he relinquished the presidency to her. The Task Force Detainees, or TFD,

\footnotetext{
${ }^{12}$ Interview with Sister Mariani Dimaranan, New Manila, Quezon City, Metro-Manila, Philippines.
} 
was dominated by women. It could loosely be classified as a women's organisation, for-although it was not an exclusively women's group - it happened to be dominated by women until the mid-1980s, when an equal number of men began to participate. The gendered nature of the TFD seemed to be a product of circumstances - the men were political detainees, and their wives formed an organisation to agitate for their release. Militant nuns and wives of detainees cooperated in order to obtain documentation clandestinely on the plight of the political prisoners. The nuns in particular were deeply involved, as their activities included smuggling documents under their habits. ${ }^{15}$

A good number of nuns risked their lives in these activities. Ang Bayan (ideological paper of the Communist Party of the Philippines, CPP) reported at least one case of a nun (pseudonym - Sister Jo) who escaped being burned to death by government militia sent to interrogate her. ${ }^{16}$ Sister Mary Bernard, a Carmelite nun, was conferred heroine status by the Bantayog ng mga Bayani for her work with the TFD for nine years (1975 1984) until she died of cancer. She too participated not because of the ideological principles of liberation theology, but because of her strong sense of justice and a desire to help those who were unfairly treated. ${ }^{17}$

Sister Christine Tan, who became Chairman of the Executive Board of the Association of Major Religious Superiors, boldly issued a memorandum to all major superiors of religious men and women that they will continue to publish Signs of the Times despite telegrams from Chairman Hans Menzi of the Philippine Council for Print-Media asking them to 'stop publishing Various Reports' ${ }^{18}$ She said that publishing the newspaper was a defence of their human rights: 'that is, the right to receive and disseminate information not carried by the controlled media, for our theological reflection,

\footnotetext{
${ }^{15}$ Interview with Sister Mariani Dimaranan.

16 'Madre, Nakatakas sa mga Pasista', Ang Bayan, February 28, 1978, p. 11; 'Sister Jo and Her Brush with Urban White Terror', Balita ng Malayang Pilipinas, February 25, 1978, p. 14. Both underground papers are in the collection held at the Cultural Centre of the Philippines.

${ }^{17}$ Sr. Mary Bernard, 'Remembering Sr. Mary Bernard Jimenez', profile, Philipppine Human Rights Update, December 15-January 14, 1990, no page; Mila Astorga-Garcia, 'Sr. Mary Bernard, Religious Activist', October 4, 1984, no page. Both articles are in the file of Sr. Mary Bernard held at the Bantayog ng mga Bayani Foundation Library, Pasig, Metro-Manila, Philippines.

${ }^{18}$ Sister M. Christine Tan, RGS, Letter Addressed to Major Superiors of Religious Men and Women on Signs of the Times, November 3, 1975, in Philippine Radical Papers, The University of the Philippines Main Library, Microfilm, Reel 09, Box 17/24.01.
} 
conscientization and Christian response'. ${ }^{19}$ The religious position was clear: 'From the start we wanted our publication to be partisan: for the poor, the suffering and the oppressed; for truth, justice and freedom. But partisanship does not prevent our publication from extending every effort to be objective, that is, to present the facts. ${ }^{20}$ Sister Christine's memorandum was issued during the time when resistance to the regime was severely punished.

Once the martial law administration declared strikes illegal, any worker who agitated for an increase in wages or improved labour conditions risked military arrest and detention. Sister Mary John Mananzan's (a Benedictine nun from St Scholastica's), 'baptism of fire' (her words) into the world of radical politics was a 1975 strike of workers at the La Tondeña wine factory. Workers approached St Scholastica's (obviously aware that nuns had 'moral' power before the nuns themselves discovered it), appealing for the support of the nuns. Four nuns responded. Once on site, the nuns linked arms (kapit-bisig) at the forefront of the picket lines to protect the striking workers. ${ }^{21}$ This became a pattern of all subsequent participation in illegal strikes. In all of these strikes, the nuns stood at the front lines. The nuns would automatically come to the front of the picket lines, using their bodies as buffer to shield and protect the workers from military violence. They believed that as dedicated members of the religious community they had the duty to protect the workers, male and female alike, if need be with their lives. ${ }^{22}$ Nuns were not immune from harm. There was never a guarantee that they would be spared; indeed they were hosed, arrested, and harassed by the military. There were incidents where nuns were beaten up at rallies. ${ }^{23}$ Despite the risks and harassment, nuns continued to join demonstrations by workers, usually for higher wages; farmers for land reform; indigenous tribes to defend their tribal lands from seizure; and human rights activists for the release of political prisoners and against human rights violations.

\footnotetext{
${ }^{19}$ Letter from Sister M. Christine Tan.

${ }^{20}$ Letter from Sister M. Christine Tan.

${ }^{21}$ Interview with Sister Mary John Mananzan, Manila, July 20, 1995.

${ }^{22}$ Interview with Sister Mariani Dimaranan.

${ }^{23}$ Interview with Sister Mariani Dimaranan; interview with Sister Mary John Mananzan, July 20, 1995; interview with Sister Christine Tan.
} 
The militant nuns elevated moral issues above political ideology By championing the causes of social justice, they also addressed the major problem faced by the Philippines in the post-war era. Here was one ideology supported by all activist groups, including the communists. The militant nuns were not just anti-Marcos or anti-capitalist: they spoke out against various problems of poverty, including malnutrition and low wages; advocated land rights for the peasantry and disenfranchised tribal groups; and fought against maltreatment of political prisoners. Stressing that they were not biased toward the left or any particular group, Sister Mariani remarked, 'We are overground, level ground, underground, whatever ground'. ${ }^{24}$ The TFD's original intent was 'We help all victims of human rights violations irrespective of ideology'. ${ }^{25}$ According to Sister Gertrude Borres, Assumption Passi (Iloilo) was established because the planters wanted a school for their children. But because they were open to everyone and because they also sympathised with the sacadas and the NPA, they were seen as 'neutral ground': 'but we became a common ground, a leveling of all these things' ${ }^{26}$

Sister Soledad Perpiñan (Sister Sol), who was already a participant in the student activism of the 1960s, was drawn, like Sister Mary John, into the vortex of radical politics in the martial law period after she participated in the La Tondeña strike. Sister Sol actually had a crucial role to play in the strike as a liaison person. Immediately after the strike, she and fellow nuns formed the Friends of the Workers, which organised Metro-Manila into four districts to facilitate support activity for the strikers: calling convents for recruits to woman picket lines; making church personnel aware of issues of social justice as well as appealing to the international funding organisations; and getting media coverage with the international press (since local media were censored). ${ }^{27}$

Her main contribution to political activism in the martial law years was as editor, writer, and founder of IBON Facts and Figures, a newsletter that produced documentation on Philippine society, economy and politics (including the underground). First published in 1978, IBON Facts and Figures became the only available accurate published reportage

\footnotetext{
${ }^{24}$ Interview with Sister Mariani Dimaranan.

${ }^{25}$ Interview with Sister Mariani Dimaranan.

${ }^{26}$ Interview with Sister Gertrude Borres.

${ }^{27}$ Interview with Sister Soledad Perpiñan, Quezon City, Metro-Manila, April 20, 1996.
} 
on current events and issues in the Philippines. Scholars, journalists and academics, particularly from overseas, relied on IBON for their data on Philippine society and economy. Sister Sol and two others were responsible for writing and editing the publication. They chose the name IBON (bird) because the symbol of a bird recalled concepts of liberty and freedom. ${ }^{28}$

Sister Josefina Magat, an Assumption nun, volunteered to be part of an international fact-finding mission which investigated the torture and murder by the military of three University of the Philippines students (around 1983). She was an officer of the Association of Major Religious Superiors in Pampanga at that time. Her involvement got her in conflict with a local bishop, who wanted to amend the final report by deleting the part which mentioned the presence of the mayor's son (he was a friend of the mayor). ${ }^{29}$

Nuns organised themselves into groups and divided tasks among themselves: some prepared the food for the rallies; some remained to pray for their comrades; and some joined the rallies in the picket lines. Until the EDSA revolution (the people-power revolution named after Epifanio de los Santos Avenue, or EDSA, where it happened), the nuns were involved in food preparation (usually sandwiches), in leading prayers, and in protecting lay men and women from the violence of the military. ${ }^{30}$ During the EDSA revolution, they cooked food and distributed food to the soldiers. Nuns armed with rosaries knelt down before armoured personnel carriers and pleaded with the military. The nuns also gave shelter and protection to other activist women escaping or hiding from military arrest. When Social Democrat Karen Tañada (KASAPI member) had to go underground, she hid in convents; ${ }^{31}$ Supreme Court Justice Cecilia Muñoz Palma found shelter among the Benedictine nuns of St Scholastica's when her dissenting opinion brought fear of reprisals; ${ }^{32}$ and Charito Planas (woman oppositionist

\footnotetext{
${ }^{28}$ Interview with Sister Soledad Perpiñan.

${ }^{29}$ Interview with Sister Josefina Magat.

${ }^{30}$ Interview with Sister Mary John Mananzan, Manila, July 20, 1995.

${ }^{31}$ Interview with Karen Tañada, Quezon City, Metro-Manila, February 7, 1996.

${ }^{32}$ Interview with Supreme Court Justice Cecilia Muñoz Palma, Quezon City, Metro-Manila, July 11, 1995.
} 
politician) escaped to southern Philippines and on to the United States protected by nuns and disguised as one of them. ${ }^{33}$

During the snap elections of 1986, Assumption nuns in the rural areas (Pampanga and Antique) walked miles to the provincial centre, where they literally hugged ballot boxes to protect them from being taken by the military. ${ }^{34}$

Secretary-General of the Citizen's Alliance for Consumer Protection from 1978, Sister Mary John Mananzan, speaking for this group, delivered speeches criticising the regime on issues such as the rise in oil prices; appeared on television speaking out against a nuclear Philippines; and argued with street police for permission to march in the streets to proclaim their stand. ${ }^{35}$ Here was a nun officially taking up the cases of all consumers, defending their rights, protecting their interests, speaking on their behalf, and demanding fair prices for essential commodities.

In the rural areas, nuns also got involved in local issues. In 1983-84, Sister Gertrude Borres was threatened with a subpoena for being in the forefront, arms linked (kapitbisig) with other clergy, protesting the demolition of squatter communities. In 1986-88 (even after martial law), she worked with Cordillera women who were against open-pit mining. ${ }^{36}$

\section{Discovering 'moral' power}

The question of whether or not the militant nuns should be considered as examples of gendered power was answered in an interview with Sister Mariani Dimaranan, who corrected my statement that nuns did not have power with the assertion, 'we got moral power'. ${ }^{37}$ What was this moral power and what are its dynamics? More importantly, how is it gendered and when did the nuns discover its potential? Sister Sol Perpiñan saw

\footnotetext{
${ }^{33}$ Interview with Vice Mayor Charito Planas, Quezon City, Metro-Manila, July 5, 1995, Chic Fortich, Escape! Charito Planas: Her Story (Quezon City: New Day Publishers, 1991).

${ }^{34}$ Interview with Sister Gertrude Borres and Sr. Maria Carmen R.A., Sing for Joy! In Grateful

Remembrance, (Manila: Religious of the Assumption Philippine-Thailand Province Centennial Year, 1992), p. 282.

${ }^{35}$ Interviews with Sister Mary John Mananzan, Manila, February 4, 1994, and July 20, 1995.

${ }^{36}$ Interview with Sister Gertrude Borres.

${ }^{37}$ Interview with Sister Mariani Dimaranan.
} 
moral power as 'real power'. ${ }^{38}$ And indeed, although more like a moral pressure or political pressure behind the scenes than overt official political power, moral power was very real in the sense that more often than not the nuns were able to influence decisions or at least escape punishment or merely 'get away with' an activity that would otherwise have been prohibited. As a priest once told sister Mariani, who was then president of the TFD, the organisation that collected documentation on the plight of political prisoners and agitated for their release: 'Kung hindi ka madre na may belo, wala na ang TFD' (If you were not a nun with a veil, the TFD would no longer be around'). ${ }^{39}$ The image of a nun (in contrast to a priest, who is male) gives the perception of someone who does not want official power, and who is therefore less threatening. The priest's statement makes the assumption that, had the president of the TFD been male and not religious, the TFD would have been demolished by the military. When nuns joined picket lines in the illegal demonstrations of the martial law regime, they would not be immediately arrested by the police or the military and would be told by them 'hindi kayo kasali' (you are not included [in this fight/cause]). ${ }^{40}$ Although it was true that the military would tend to leave the nuns unharmed, they sometimes arrested them or subjected them to physical violence or beatings. In the agitation for land reform rights and the fight for indigenous land in particular, some nuns suffered arrest and violence. ${ }^{41}$

The nuns became aware of the potential of moral power when they became political activists. In various written circulars and statements, nuns of various religious orders saw their role not just as helping the victims of martial law, but also as providing help in the evolution of martial law policies, directives and decrees, by making these more compliant with human rights and freedoms (E.g. through CEAP, parents obtained favourable reaction from PAF regarding the CAT Program to be carried out for Girls' High Schools). ${ }^{42}$ In 1984, several religious orders released statements calling for a boycott or non-participation in the elections. ${ }^{43}$

\footnotetext{
${ }^{38}$ Interview with Sister Soledad Perpiñan.

${ }^{39}$ Interview with Sister Mariani Dimaranan.

${ }^{40}$ Interviews with Sister Mary John Mananzan Manila, February 4, 1994, and July 20, 1995.

${ }^{41}$ Interview with Sister Soledad Perpiñan.

42 'Religious of the Assumption - Summary of Reflections on AMRSP's Survey', Files, Association of Major Religious Superiors, New Manila, Quezon City.

${ }^{43}$ Sisters' Association in Mindanao (SAMIN), 'A Statement of Conscience on the Immorality of the 1984 Plebiscite and Election', January 15, 1984,'Statement of the Good Shepherd Sisters on the January
} 
Apart from making official statements of their political positions, the nuns also joined or formed organisations with overt oppositional political agendas. For example, Sister Sol and Sister Mary John were involved in 'Friends of the Workers' - an organisation that helped workers who were striking for better conditions (strikes were illegal during martial law). Sister Sol knew that IBON's database was used by the workers (including the Benguet gold miners) during collective bargaining. ${ }^{44}$ Here was a clear example where her research and writing gave workers the ammunition for their political and economic struggles. Sister Sol founded BALAI - a group interested in environmental issues, which produced its Asian journal. ${ }^{45}$ By 1994, Sister Mary John was already leading a Welga Ng Bayan (National Strike).

The nuns' image as moral guardians or religious figures, coupled with their role as defenders of the oppressed victims of martial law, gave them both moral power and legitimacy. Both Sister Gertrude Borres and Sister Josefina Magat affirm that their credibility as nuns working for social justice gave them legitimacy in the community. ${ }^{46}$ In some cases, they were able to protect the workers from being arrested, ${ }^{47}$ allow an overtly anti-regime organisation (TFD) to survive, smuggle documents inside their habits ${ }^{48}$ and negotiate with the military for more physical space at rallies. ${ }^{49}$ Their potential moral power was recognised by then First Lady Imelda Marcos, who invited Sister Christine Tan four times to have an audience with her at Malacañang palace. Defense Minister Juan Ponce Enrile also called Sister Christine Tan to discuss Sister Sol Perpiñan's activities (Sister Christine was her provincial superior). ${ }^{50}$ The classic example of the efficacy of moral power is the 'People Power Revolution' of 1986, when nuns armed with rosaries, along with unarmed civilians, faced the military in armoured

Plebiscite and May Election', Kapisanan ng Mga Madre sa Kamaynilan (KAMAY), 'Pahayag ng Kamay sa Darating na Eleksyon' and 'Kamay Statement of the May '84 Election', all in Papers, Association of Major Religious Superiors, Quezon City,

${ }^{44}$ Interview with Sister Soledad Perpiñan.

${ }^{45}$ Interview with Sister Soledad Perpiñan.

${ }^{46}$ Interview with Sister Gertrude Borres and interview with Sister Josefina Magat.

${ }^{47}$ Interview with Sister Soledad Perpiñan.

${ }^{48}$ Interview with Sister Marianin Dimaranan

${ }^{49}$ Interview with Sister Mary John Mananzan

${ }^{50}$ Interview with Sister Sol Perpiñan. Sister Mary John was also told by a friend in the military that there was a file on her. 
personnel carriers. Faced by these ultimate symbols of moral and religious power, and surrounded by praying civilians, the military hesitated to use violence. The image of nuns in white, kneeling down and saying the rosary in front of heavily armed soldiers, encapsulates the confrontation between two types of gendered power: the macho military man, representing the political power of the army with all its associations with male violence and the non-violent nun, who does not seek political power (represented by her kneeling down and praying), but who exudes moral power.

In the snap elections of 1986 , the rural areas were more vulnerable to violence and tampering of ballot boxes. Sister Josefina Magat was assigned to one polling area in Pampanga. During the elections, a group of armed men fired shots and entered the polling place. By coincidence, the leader recognised Sister Josefina as the nun who reported a robbery at the police precinct a week earlier and he immediately apologised ('Sorry, po, sorry po'). No one was harmed and the nuns were permitted to carry the ballot boxes to the municipal office. Sister Josefina believed that, had she not been a nun and someone who actually knew the person in charge, another nun and public school teachers watching the ballot boxes may have been harmed. ${ }^{51}$

The recognition of the force of nuns' 'moral power' meant that they could be manipulated or used by political groups. Sister Gertrude identified her 'baptism of fire' (her words) as the day the NPA used her moral authority among the peasant workers in Passi, Iloilo to encourage a violent confrontation with the military. In 1983, when she was superior of Assumption Passi Iloilo, the peasants entered the city by force and confronted the military. She intervened and convinced the group of farmers to stay in the convent for two days. Unlike Sister Mary John's 'baptism of fire', Sister Gertrude's was one of disillusionment. In the early morning, at around 4 am, the group went to the police station without letting her know that they were planning a violent confrontation with the military. She immediately closed the school and organised buses for people to leave just at the time the military began to surround the convent. ${ }^{52}$

\footnotetext{
${ }^{51}$ Interview with Sister Josefina Magat.

${ }^{52}$ Interview with Sister Gertrude Borres.
} 
But once the nuns tasted the fruits of moral power, some translated these to actual official political power quickly after 1986 (when martial law ended). Sister Christine Tan was invited by the incoming President Corazon Aquino to be a member of the Constitutional Convention to give the urban poor a voice in the writing of the new constitution of the republic. In fact, Sister Christine has become somewhat of a celebrity appearing constantly on television and in the print media as a critic of presidential administrations, from Aquino to Estrada. Sister Sol Perpiñan, through her involvement with NGOs, often attends the United Nations international conferences, where she is an official voice for advocate groups. ${ }^{53}$

The nuns' habit also became a powerful symbol of moral power; and nuns as well as priests were extremely conscious of its 'spiritual potency'. Sister Gertrude was quick to point out that martial law was post-Vatican II and nuns and priests received a directive from Rome to dress like the laity and discard the nun's wimple for example. The aim of this directive was to ensure that the religious blended with the community and therefore would not be subjected to special treatment, such as seats in a full bus, for example. But she was quick to observe that, during demonstrations, the nuns appeared in full habit (complete with veil) and the priests showed up attired in their sutanas. ${ }^{54}$ The nuns' habit symbolised moral power and had to be worn as an expression of that power. It signified both moral power and protection from male military might (symbolised by military men in uniforms carrying guns). It produced a visual contrast between female moral power and macho military might.

\section{Enter Feminisms}

Though militant nuns were very visible as political agents, there were only a handful of them at the start of martial law: only 200 radical nuns, out of a total of 9000 nuns in the country. While not all nuns were political radicals, the religious of St Joseph's and St Scholastica's, the Franciscan nuns, the Assumption nuns and the Good Shepherd nuns were among those particularly active.

\footnotetext{
${ }^{53}$ Interview with Sister Soledad Perpiñan.

${ }^{54}$ Interview with Sister Gertrude Borres.
} 
It was these same radical nuns, from that small group of 200, who metamorphosed into feminists. Although the first feminist organisation in the Philippines was formed in the late 1960s as part of the Nationalist Youth, the MAKIBAKA (Malayang Kilusan ng Bagong Kababaihan, or Free Movement of New Women) was forced to go underground, aborting prematurely its mutation into a probable feminist movement with a nationalist orientation or, alternatively, a nationalist movement with a feminist orientation. It was only then beginning to criticise cultural constructions of the feminine, but still prioritised national liberation over women's issues.

The transformation from militant nun to feminist occurred in stages. Even prior to martial law, some nuns were already questioning the disparity between the life of poverty lived by millions of Filipinos outside the convent walls and the relatively secure and comfortable life in the cloisters. Sister Christine said she was feeling that somehow her vocation was 'fake', because of this disparity (and she herself came from a very wealthy family). ${ }^{55}$ These nuns asked permission to live among the urban poor. Both Sister Christine and Sister Sol chose to live in the slum areas. Sister Gertrude Borres wanted to work in the rural areas, so she was assigned to Assumption Passi, Iloilo and Sister Josefina Magat was assigned to San Simon Pampanga to teach in the vocational school for the poor there. ${ }^{56}$

Thus, prior to 1972, these nuns were already involved in organising 'conscientisation seminars', where they spoke to their congregation and other religious orders about their new vocation of living with the poor. When martial law was declared, these same nuns organised 'conscientisation seminars', but this time the topic was martial law and the clergy's new role in the politically oppressive regime. The nuns therefore already had experience in organising and giving seminars designed to rethink their roles as religious in response to the times. They also already had the infrastructure with which to discuss and disseminate these new ways of thinking about themselves. Conscientisation seminars are defined by the nuns themselves as consciousness-raising of one's basic political rights or human rights in the context of a social class. To them, feminism is the

\footnotetext{
${ }^{55}$ Interview with Sister Christine Tan

${ }^{56}$ Interview with Sister Gertrude Borres, interview with Sister Josefina Magat.
} 
conscientisation of women in terms of their basic human rights, in the context of oppression by men. ${ }^{57}$

In the late 1970s and early 1980s, some nuns were exposed to Western feminist ideas through overseas conferences. Both Sister Mary John Mananazan and Sister Soledad Perpiñan cite these overseas contacts as influential in shaping their feminist consciousness. ${ }^{58}$ Sister Gertrude Borres was in Paris from 1994 to 1999 when she was elected to the General Council of Assumption sisters. ${ }^{59}$

But a crucial factor that triggered empathy for Western feminist issues was the contrast between the 'moral power' they exercised politically and the fact that 'in the church we have no voice' ${ }^{60}$ In assemblies and political meetings, the nuns were assigned secretarial tasks, whereas the priests were often the speakers. ${ }^{61}$ On the exclusively male leadership of the church, Sister Christine said: 'I have much against the male in the church, because they make all our laws, particularly about giving birth and abortions' ${ }^{62}$ She also noted the contradiction between the women's lack of power in the church and the nuns' success in pressuring the bishops (who originally were silent) to declare martial law as illegal. ${ }^{63}$ Such vocal criticisms of church patriarchy, as well as the political activism of these nuns, have provoked repercussions: Sister Christine, along with five sisters, was sent out of Manila and threatened with excommunication. ${ }^{64}$

The nuns were therefore political activists before they became feminists, ${ }^{65}$ because it was the discovery of the disparity between the moral power they exercised as activists and their lack of power in the church that gave them first-hand experience of women's inequality. How is it possible to exert influence on a military dictatorship, while being ignored in the church hierarchy? According to Sister Mary John (the ultimate example

\footnotetext{
${ }^{57}$ Interview with Sister Gertrude Borres.

${ }^{58}$ Interviews with Sister Mary John Mananzan, Manila, February 4, 1994 and July 20, 1995, interview with Sister Soledad Perpiñan.

${ }^{59}$ Interview with Sister Gertrude Borres.

${ }^{60}$ Interview with Sister Christine Tan.

${ }^{61}$ Interview with Sister Sol Perpiñan.

${ }^{62}$ Interview with Sister Soledad Perpiñan

${ }^{63}$ Interview with Sister Christine Tan.

${ }^{64}$ Interview with Sister Soledad Perpiñan
} 
of the feminist nun, whose feminists activities have been described by Claussen as 'legendary') nuns were used to being underprivileged more than priests and they were in the best position to be feminists, because they could prove that they could live without a man. ${ }^{66}$ At the same time, their previous experience in conscientisation seminars ${ }^{67}$ meant that they had the organisational structure with which to disseminate their ideas to the rest of their congregation and then, through women's organisations and women's studies courses, to society at large.

In 1980, Sister Mary John Mananzan founded the feminist organisation PILIPINA, and in 1985, she founded the first Institute of Women's Studies in the Philippines at St Scholastica's College. As Dean of the College of Arts and Director of the Women's Studies Institute, Sister Mary John has been influential in spreading feminist ideas to the student body: women's studies is a compulsory subject at St Scholastica's; that is, no woman can graduate without taking this subject. As head of the Institute of Women's Studies, Sister Mary John has introduced new courses that examine the patriarchal elements of Filipino society, where males are privileged and spoiled and women seek to become self-sacrificing mothers, morally bound to the home. The introduction of courses focusing on the discourse on the woman question, with an emphasis on the specific Philippine situation, exudes a feminist critique of the cultural construction of both the feminine and the masculine, an important landmark in the evolution of feminism in the Philippines. In the process, she has refrained from merely grafting Western feminist theories uncritically onto the Philippine situation. On her own, she consciously chose to break away from the Western feminist perspective:

We [PILIPINA] make it a point to distinguish ourselves from some Western feminists kasi [because] sometimes they trivialize the whole thing, they make it a man-against-woman thing which we don't believe in. With us, it's a matter of how you get a woman to really maximize her whole potential. ${ }^{68}$

\footnotetext{
${ }^{65}$ Interview with Sister Christine Tan, interview with Sister Mary John Mananzan, Manila, February 4,1 994, interview with Sister Soledad Perpinãn.

${ }^{66}$ Interview with Sister Soledad Perpiñan; interview with Sister Mary John Mananzan Manila, February 4, 1994, and July 20, 1995.

${ }^{67}$ Interview with Sister Gertrude Borres.

${ }^{68}$ Jose F. Lacaba, tape reporter, 'Sister Mary John Mananzan: Christian and Citizen,' periodical and date not mentioned, filed in Sister Mary John Mananzan's personal scrapbook, Nursia, The Institute of Women's Studies, St. Scholastica's College, Manila.
} 
Women's Studies workshops and seminars are also given to women in grassroots organisations at St Scholastica's. Her influence as a charismatic nun has also been cited by fellow Benedictine nuns as the reason why they also became feminists (Claussen 1998, using the pseudonym Sister Justine). She was also cofounder of the Center for Women's Resources in 1979. She has written articles on the woman question in the Philippines, researched the status of women in prehistory and historical times, and published on women's issues. ${ }^{69}$ She is also an active member of the editorial board of Lila Asia Pacific Women's Studies, Journal, an academic journal that publishes on women's issues in the Asia-Pacific region. In 1986, GABRIELA began to involve itself primarily in women's issues and perhaps it was no coincidence that Sister Mary John assumed presidency of that body in that year. The issues of mail-order brides, prostitution, trafficking in women, the comfort women and women migrants overseas, including domestic helpers, were given priority. By 2002, negotiations began which would bring together common women's studies courses/agendas for five universities: St Scholastica's, Assumption College, Miriam College, Holy Spirit and St Paul's Quezon City. ${ }^{70}$

While Sister Mary John concentrated on educating women or 'conscientising' women on feminist issues, Sister Sol focused on the issues of prostitution, sex tourism and the trafficking of women in particular. She founded Third World Movement Against the Exploitation of Women (TW-MAE-W) in 1982. The organisation was originally established in order to protest Japanese sex tours and prostitution in Manila and the military bases. It later expanded its concerns to include the mail-order bride phenomenon and Filipino prostitution overseas, like the Japayukis in Japan.

Sister Christine Tan, who served as chair of the Association of the Major Religious Superiors of Women in the Philippines, criticised the church's viewpoint on issues that affect women, like birth control and abortion. Although she supported the anti-abortion stance of the church, she stressed that women have the right to determine what would be good for their own body. As a delegate in the 1986 Constitutional Convention, she was

\footnotetext{
${ }^{69}$ See Mananzan (n.d.; 1987; 1988) and Mangahas and Mananzan (1989).

${ }^{70}$ Interview with Sister Gertrude Borres.
} 
against the pro-life provision (Custodio 1986). Contrary to the church's official position, Sister Christine advocated family planning through artificial means. ${ }^{71}$

The nuns in their different orders also reflect the various feminisms. The Assumption nuns do not identify closely with Sister Mary John's or Sister Christine's feminism, which they find combative. They don't see their being feminist as necessarily challenging the male hierarchy of the church. They would like to see women develop their full potential (and in fact, interestingly, teach feminism in a theology class, which they call Apostolic Spirituality ${ }^{72}$ ) but do not overtly challenge the patriarchal nature of church hierarchy. Sister Gertrude says the Assumption foundress's view of women's power is not combative: 'it is discovering your own being and because you are able to discover your own being, it is that - that you bring to society and that is where you make a difference ${ }^{73}$ Perhaps this is because the Assumption nuns I have spoken to have not had serious confrontations with male church hierarchy or have been able to resist (Sister Josefina, for example, resisted the Bishops' directive to remove the name of the mayor's son in the fact-finding report). One clear strategy seems to be the attempt to redefine the vow of 'obedience' to mean that one must follow one's conviction (whether the superior be a man or a woman) ${ }^{74}$ And by and large, these nuns were confident that they were able to follow their conscience. A group of male American friends told Sister Josefina: 'I wish you were more aggressive,' to which she calmly responded: 'I say no, I am a Filipina. They cannot understand the paradigm. We can get what we want. ${ }^{75}$

\section{The Militant Nun/Feminist Nun Here to Stay Beyond Martial Law (post-1986)}

Not all militant nuns would be comfortable with the 'feminist' label, no matter how broadly one defined feminism (since feminism is still an ' $F$ ' word in the Philippines, with women exercising both official and unofficial power and even women in radical

\footnotetext{
${ }^{71}$ Neomi Tanedo Olivares, 'Erring' Catholic Leaders', letters, newspaper publication not identified, in the scrapbook on Sister Christine Tan, compilation of newspaper clippings about her activities held by her godchild Paulette, Women's Desk, Association of Major Religious Superiors, Quezon City, MetroManila.

${ }^{72}$ Interview with Sister Gertrude Borres.

${ }^{73}$ Interview with Sister Gertrude Borres.

${ }^{74}$ Interview with Sister Josefina Magat.

${ }^{75}$ Interview with Sister Gertrude Borres.
} 
politics hesitant to call themselves feminist) ${ }^{76}$. After 1986 (when martial law ended), the nuns who had metamorphosed into political activists did not return to the cozy statusquo cocoon once the democratic institutions were restored. Though some might have tasted a modicum of official power (like Sister Christine), they have chosen to continue to represent the voices of the oppressed, the poor, those suffering injustice. In the end, even someone like Sister Christine, Sister Mariani, and Sister Mary John chose to continue their political activism even after the fall of Marcos. Sister Christine eventually felt morally obliged to announce her disillusionment with the regime of President Corazon Aquino: 'The present leadership has failed us'. ${ }^{77}$ She attacked the Aquino government as 'elitist, corrupt and failing to meet the country's basic needs', faulting Aquino herself for not being more decisive and reviewing her achievements as follows: 'She restored for us a sense of pride but the people around her are not as sincere and honest. ${ }^{78}$ The price of her continuing political activism was an estrangement with President Aquino, costing her access to unofficial power. She persisted in participating in protests and rallies, including one that presented a play depicting the sufferings of the urban poor $^{79}$ and one that submitted to President Aquino proposals from a delegation of urban poor demanding a stop to the demolition of squatter communities and/or their relocation to sites a great distance away from their places of work. ${ }^{80}$ That her continued activism was still fueled by her moral concern was evidenced by her rhetorical question, 'Is a [sic] legal necessarily moral?' Sister Christine was lamenting the fact that, despite promises by members of the Constitutional Convention that they would not run for office (for ethical reasons), some had gone back on their word and sought elective office. ${ }^{81}$ In the Estrada administration (1998-2001), she has been a controversial figure

\footnotetext{
${ }^{76}$ Heather Claussen's study (1998) of the Benedictine nuns confirms this. In my research on women and power in post-war Philippines, all interviewees except the militant nuns were uncomfortable with the term (Roces 1998).

77 'Sister Christine Tan Playing Down the Cory Cult', Midweek, March 9, 1988, p. 1.

78 'Prominent Nun Hits Cory Gov't', c.May 1987, in the scrapbook on Sister Christine Tan (periodical not identified) kept by her godchild Paulette at the Women's Desk, Association of Major Religious Superiors, Quezon City, Metro-Manila; 'Nun Assails Gov’t as Elitist, Corrupt', Star, May 16, 1987, n.p. in the same scrapbook.

79 'Urban Poor Persecuted in 'Calvary', Malaya, April 18, 1987, n.p. in the scrapbook on Sister Christine Tan.

${ }^{80}$ Teodoro Y. Montelibano, 'Gov’t Prepares Expanded Land Reform Program', n.p., n.d., in the scrapbook on Sister Christine Tan.

${ }^{81}$ Sister Christine Tan, 'Sister Christine's Personal Grief,' Letters to the Editor, n.p., n.d., in the scrapbook on Sister Christine Tan, periodical not identified.
} 
appearing often on television, particularly in the scandal involving the Philippine Charity Sweepstakes.

As Chair of the Citizen's Alliance for Consumer Protection, Sister Mary John criticised President Fidel Ramos's increase in oil prices, the expanded value-added tax (E-VAT), and the structural dynamics of a society where corruption was still rampant and only ten percent of the population benefited from economic reform. ${ }^{82}$ True to form, nuns in groups were at the forefront of demonstrations against the E-VAT. ${ }^{83}$

Sister Mariani Dimaranan clashed with Cardinal Jaime Sin during the Aquino demonstration (1986-1992), when he announced that there were no more political detainees under the Aquino administration, despite the fact that TFD had clearly found evidence to the contrary. ${ }^{84}$ In more recent times, the militant nuns were again out in full force in 'EDSA Dos' or 'People Power II' in January 2001, when demonstrations and cabinet resignations caused the ouster of President Joseph Estrada. True, Cardinal Jaime Sin was at the forefront of the campaign to pressure Estrada to resign, but the nuns were there just as they were in the 1986 'People Power I Revolution'. Assumption nuns brought students to the Senate hearings and participated in anti-Estrada rallies. Even their mother superior was present in EDSA Dos. ${ }^{85}$

Yet, while the militant nuns have succeeded in exercising political power behind the scenes as activists holding 'moral' power, they have been less effective in acquiring a voice within the patriarchal church hierarchy. The nuns' predicament is also a classic example of how women's power in the Philippines has remained a contested site, where ambivalence and contradictions are the norm. The contesting discourses of kinship politics and modernity are played out and negotiated through women's power. The nuns were not only political activists, but also feminists (modern). However, their moral power was exercised unofficially. Refusing to claim official power, the nuns acted as a pressure group, lobbying politicians to initiate political and social change. Perhaps that

\footnotetext{
${ }^{82}$ Personal communication with Sister Mary John Mananzan, Metro-Manila, February 22, 1996.

83 'Protests Spread Nationwide', with picture caption 'Nuns Are Once More in the Forefront of Protest

Marches', Philippine Daily Inquirer, January 31, 1996, p. 1.

${ }^{84}$ Interview with Sister Mariani Dimaranan.

${ }^{85}$ Interview with Sister Josefina Magat.
} 
is the reason for their effectiveness: though they demanded modern ideas and full equality and empowerment for women, they did so in the traditional way women exercised power. At the same time, they exuded contrary images: traditional images of women as moral guardians and modern images of women as militant (mataray - tough and militant, not sweet and placid) ${ }^{87}$ and feminist. Since the martial law era, Philippine society has acknowledged the political influence of the militant nun - such moral power has been institutionalised with the presence of nuns in almost every demonstration involving social justice. But their feminist crusade within the church hierarchy has remained lacklustre. While moral power quickly became political power, enabling the nuns in political women's organisations to influence pro-women legislation, nuns remained marginalised in the hierarchy of the Catholic Church. Perhaps, moral power is effective in Philippine local politics (since men dominate official power), but feminist power is not translatable to real power in the Catholic Church. The Catholic Church, after all, transcends local barriers and has remained far more male-dominated than Philippine politics in the twentieth century.

\section{Reference List}

Aguilar, D.D. 1988, The Feminist Challenge: Initial Working Principles Toward Reconceptualizing the Feminist Movement in the Philippines, Asian Social Institute, Metro-Manila.

-1994-95, 'Toward a Reinscription of Nationalist Feminism', Review of Women's Studies 4, 2.

Angeles, L. 1989, Feminism and Nationalism: The Discourse on the Woman Question and the Politics of the Women's Movement in the Philippines, 1900-1988, MA thesis, University of British Columbia.

Claussen, H.L. 1998, Un(convent)ional Sisterhood: Feminist Catholic Nuns in the Philippines, Phd Dissertation, University of California, San Diego.

De Dios, A.J.J. 1996, 'Participation of Women's Groups in the Anti-Dictatorship Struggle: Genesis of a Movement', in Women's Role in Philippine History: Selected Essays, Quezon City, University Center for Women's Studies, University of the Philippines.

Gomez, M. 1991, 'Women's Organizations as Offshoots of National Political Movements' in Sister M.J. Mananzan (ed.) Essays on Women, Manila, Institute of Women's Studies, St. Scholastica's College.

\footnotetext{
${ }^{86}$ Interview with Sister Mary John Mananzan July 20, 1995. She lamented that the military and police often referred to her as mataray (unfeminine).

${ }^{87}$ Interview with Sister Mary John Mananzan July 20, 1995. She lamented that the military and police often referred to her as mataray (unfeminine).
} 
Hilsdon, A. 1995, Madonnas and Martyrs: Militarism and Violence in the Philippines, Ateneo de Manila University Press, Quezon City.

Hyndman, N.N. 1992, Speaking for the 'Filipina' Feminist Scholars and National Liberation in the Philippines, BA Honours thesis, Australian National University.

Liberation, November 12, 1973, pp. 1-2. Copy available from the Cultural Centre of the Philippines library.

Mananzan, Sister M.J. (ed.) 1992, Woman and Religion. Metro-Manila: Institute of Women's Studies, St. Scholastica's College.

- (ed.) 1987, Essays on Women, Metro-Manila: Institute of Women's Studies, St. Scholastica's College.

- (ed.) (N.D.), The Woman Question in the Philippines, pamphlet, Metro-Manila: Institute of Women's Studies, St. Scholastica's College.

Mangahas, F., and Mananzan, Sister M.J. (eds) 1989, Sarilaya: Women in the Arts and Media, Metro-Manila: The Institute of Women's Studies, St. Scholastica's College.

Roces, M. 2001, 'Women in Philippine Politics and Society' in H. McPherson (ed.) Mixed Blessing: The Impact of the American Colonial Experience on Politics and Society in the Philippines, Greenwood Press, Westport, Connecticut, and London.

-1998, Women, Power, and Kinship Politics: Female Power in Post-War Philippines, Praeger, Westport.

Ronquillo, S. 1984, 'MAKIBAKA Remembered', Diliman Review 42, 3-4.

Santos-Maranan, A.F. 1984, 'Do Women Really Hold University Press Half the Sky?' Diliman Review, May-August.

Tangcangco, L.C. 1992, 'Voters, Candidates, and Organizers: Women and Politics in Contemporary Philippines' in P.D. Tapales (ed.) Filipino Women and Public Policy, Kalikasan Press, Manila. 